\title{
ОРФОГРАФИЧЕСКАЯ ПРОБЛЕМА БУКВЕННОГО РЕГИСТРА И ЕЕ ОТРАЖЕНИЕ В ЛЕКСИКОГРАФИИ
}

\author{
ИЯ НЕЧАЕВА \\ Российская академия наук \\ Институт русского языка им. В. В. Виноградова \\ ул. Волхонка, 18/2, 119019 Москва, Россия \\ e-mail: inechaeva@mail.ru \\ ORCID: https://orcid.org/0000-0003-3421-1714 \\ (получено 16.08.2018; принято 18.09.2018)
}

\section{Abstract \\ Orthographic problem of letter case and its reflection in lexicography}

The paper analyzes the orthographic problem of capital vs. small grapheme usage from the perspective of lexicographic description. In this area the orthography is largely related to extralinguistic reality and is frequently complicated by the factor of orthographic tradition. The determination of the status of a nomination as a proper name is not always evident; furthermore, there exist numerous transitional cases. The existence of multiple factors influencing orthographic solutions and the existence of individual orthographic norms are responsible for the specific character of lexicographic description. The problem of letter case is described in a specialized orthographic dictionary, since general dictionaries usually disregard it.

The special features of the usage of a capital grapheme may be related to the semantics of lexical units (mono- and polysemantic) or to their structure (one-word or not-one-word units). Relevant examples are given and analyzed in the paper. Also, common orthographic correlates of proper names are included in dictionaries. The optimal form of lexicographic description is a dictionary complex which comprises all borderline cases. 


\section{Key words}

Orthography, lexicography, letter case, capital letter (grapheme), proper name, common name, onym, appellative, aspect dictionary.

\section{Резюме}

В статье анализируется орфографическая проблема употребления прописной vs. строчной графемы в аспекте лексикографического описания. Правописание в данной области в большой степени связано с внеязыковой реальностью и нередко осложняется фактором орфографической традиции. Определение статуса номинации как имени собственного не всегда очевидно; кроме того, существует значительное количество переходных случаев. Многофакторность орфографических установлений и наличие индивидуальных правописных норм обусловливает специфику словарного описания. Проблема буквенного регистра описывается в специализированном аспектном орфографическом словаре, поскольку словари общего плана обычно оставляют ее без внимания.

Особенности употребления прописной графемы могут быть связаны с семантикой словарных единиц (моно- и полисемантических) или с их структурой (однословных и неоднословных). В статье приводятся и анализируются соответствующие примеры. В словарь включаются также нарицательные орфографические корреляты собственных имен. Оптимальную форму словарного описания представляет словарный комплекс, включающий все пограничные случаи.

\section{Ключевые слова}

Орфография, лексикография, буквенный регистр, прописная буква (графема), имя собственное, имя нарицательное, оним, апеллятив, аспектный словарь.

Практически любая орфографическая проблема может быть описана лексикографически. Существуют общие (универсальные) орфографические словари, предназначенные для орфографически корректного представления всего лексического массива языка в соответствии с правилами правописания и научными установками авторов данного словаря. Они могут быть дифференцированы по объему и адресату: создаются максимально полные на момент своего выхода словари, а также малые, краткие и карманные; с другой стороны, есть словари для широкого читателя и словари учебные, предназначенные для какой-л. конкретной категории пользователей, отличающиеся определенным уровнем адаптации словарной информации. Универсальные словари не акцентируют внимание читателя на какой-либо конкретной проблеме, они приводят справочную 
информацию общего орфографического плана, представляя собой более или менее подробный список нормативно корректных написаний.

Существует также и другая группа лексикографических изданий: это аспектные орфографические словари, предметом описания которых является какая-либо одна правописная проблема: например, правописание сложных слов и словосочетаний, или употребление удвоенных согласных, или употребление прописной буквы (графемы) ${ }^{1}$. Необходимость компактного словарного отображения проблемных в определенном отношении слов и практическая потребность в такого рода пособиях привела к созданию словарей Слитно или раздельно?, Прописная или строчная и Одно или два «н»? (см. Букчина, Калакуцкая, 1982/1987; Розенталь, 1984; Лопатин, Нечаева, Чельцова, 1999/2009; Сазонова, 1999).

Аспектные (иначе - профильные) словари описывают однопорядковые языковые единицы либо рассматривают лексику под определенным углом зрения (см. Крысин, 2013, с. 557). Орфографические словари, посвященные одной теме, имеют своим предметом описание лексического материала, вычленяемого по формально-графическому признаку, будь то удвоение согласных, прописная графема или дефисно-пробельно-контактное присоединение значимых частей лексической единицы. Графические особенности выделенных категорий слов являются в определенной мере показателем их языкового статуса. Это могут быть адъективно-причастные формы (которые не исключительно, но преимущественно составляют словарь Одно или два «н»?), собственные имена и наименования (Прописная или строчная?) или сложные с точки зрения как синхронии, так и диахронии слова и словосочетания (Слитно или раздельно?). Однако при определении статуса языковой единицы, равно как и ее письменной формы, необходим инструмент сравнения, привлекаемый для решения орфографической задачи.

Проблему буквенного регистра орфографические словари общего плана обычно оставляют без внимания. Процесс «изгнания» прописной из общего орфографического словаря, произошедший в середине 20 века и обусловленный, вероятно, конъюнктурными причинами, описан в статье В. В. Лопатина 2001 года (Лопатин, 2001, с. 250-253). Частично ономастическая лексика и связанные с ней орфографические проблемы были возвращены в Русский орфографический словарь под ред. В. В. Лопатина при формировании концепции его 1-го издания (1999). Между тем данная область орфографии в современной практике письма наименее устойчива и потому заслуживает отдельного подробного описания, которое имеет свои особенности. Этим обусловлена необходимость создания аспектного словаря.

Очевидно, что в системе языка собственные имена связаны с нарицательными семантическими, деривационными и иными связями, тем самым создавая смысловое поле смежных понятий и соответствующих им лексем. Это предпо-

\footnotetext{
1 Вопреки распространенному наименованию «прописная буква», мы будем использовать словосочетание «прописная графема», являющееся терминологически более точным; см. Зализняк, 1979, с. 146; Нечаева, 2017, с. 144.
} 
лагает включение в словарь, наряду с собственными именами, и коррелирующих с ними нарицательных имен (например: Гулливер 'литературный персонаж' и гулливер перен. 'очень высокий человек'; компас 'прибор' и Компас 'созвездие'; Бордо 'город во Франции' и бордо 1. 'сорт красного вина', 2. 'цвет'; земля 'суша, почва, территория' и Земля 'планета' и др.). Значения и орфография подобных единиц эксплицируются путем взаимного сопоставления в рамках семантической пары (или семантического ряда). В связи с этим словари описываемого жанра по своему составу являются гибридными.

С другой стороны, распределение лексики на онимо-апеллятивных полюсах (а иногда и на шкале постепенных смысловых переходов) не всегда является очевидным. Немало переходных случаев, когда статус той или иной номинации находится в стадии формирования и противопоставление графических пар по признаку регистра начальной графемы не является окончательным (Чельцова, 2009, с. 254-255) (например: Иуда 'евангельский персонаж' - иуда 'предатель', Робинзон 'литературный персонаж' - робинзон перен. 'тот, кто живет в необитаемой местности'; но: Плюшкин 'персонаж Н. В. Гоголя' - Плюшкин 'скряга', Наполеон 'французский полководец и император' - Наполеон 'властолюбивый и самонадеянный человек, претендующий на исключительность’ т.п.). Вынесенная в заглавие словаря вопросительная формула отражает проблему орфографического выбора и соответствует жанровой специфике аспектного словаря. В такой словарь включаются слова и словосочетания, которые могут писаться как с прописной, так и со строчной графемы или у которых вариант написания с прописной можно заподозрить. Надо сказать, что аспектные орфографические словари в большей степени, нежели универсальные словари, апеллируют к языковой компетенции читателя.

Орфографическая проблема буквенного регистра имеет два основных аспекта: регистровая мена может происходить как в зависимости от членения речи, так и независимо от этого. В первом случае говорят о синтаксической функции прописной графемы (употребление в начале самостоятельного отрезка текста), во втором случае - о семантической функции. Помимо этого можно говорить о стилистической функции прописной и о функции, которую мы назовем этикетной (Нечаева, 2017, с. 157).

Лексикографическому описанию подлежат те случаи регистровых различий, которые не зависят от членения речи, т.е. в основном речь идет о семантической функции. Данная функция задействована при обозначении с помощью прописной особого характера слова, присущего собственным именам.

Принципы орфографического подхода в данной области заданы в основном Я. К. Гротом (хотя вопросы уместности употребления прописной были предметом внимания ученых и до Грота). Известны его высказывания о желательности разумной экономии при употреблении прописных на письме: «Большія буквы составляют, собственно говоря, роскошь письма» (Грот, 1888, с. 87); «Слишкомъ пестрить письмо большими буквами конечно не годится, но съ другой стороны и слишкомъ тщательно избъгать ихъ нътъ основанія: большія буквы во многихъ случаяхъ доставляютъ ту практическую пользу, что при бъгломъ чтеніи или при пересмотрь прочитаннаго даютъ глазу точки опоры, 
облегчаютъ ему отысканіе нужнаго» (Грот, 1876, с. 359). Основная идея заключается в следующем: «Совершенно справедливо признать за общее правило, что съ большой буквы пишутся только слова, служащія собственными именами; но такую роль могутъ играть не одни въ тъсном смыслъ означаемыя этимъ названіемъ слова, а также и нарицательныя - какъ существительныя, такъ и прилагательныя»; «Относительно названій, состоящихъ изъ нъсколькихъ словъ, возникаетъ вопросъ: всъ ли эти слова писать съ большой буквы, или только главное изъ нихъ? Держась принятаго принципа не расточать большихъ буквъ, сльдует начинать такою буквою только первое слово подобныхъ названій» (Грот, 1876, с. 360).

Но, как уже отмечалось, не всегда легко различить имя собственное и имя нарицательное. Критерии, определяющие статус наименования, неабсолютны. В теории для онимов характерна непосредственная связь с денотатом, они несут в себе десемантизирующую составляющую и не обозначают понятие (поддающееся дефиниции), а являются лишь меткой для какого-л. объекта; при этом онимы выполняют функцию индивидуализации понятия и указывают на единичность обозначаемого ими денотата (Суперанская, 1973, с. 56-57). В целом принимая данное теоретическое исследование за основу понимания языкового статуса имени собственного, можно, однако, заметить, что на практике задача разграничения онимов и апеллятивов иногда очень сложна, поэтому общих представлений о понятии имени собственного, а также существующих правил в этом сегменте правописания порой оказывается недостаточно. Так, наблюдения за узусом показывают, что существуют вторичные онимы, не прошедшие стадию десемантизации и сохраняющие в той или иной степени семантику апеллятива (например, Рождество, Вознесение, Иоанн Креститель, Болеслав Храбрый, Вильгельм Завоеватель, Кощей Бессмертный, иаревна Несмеяна, синьор Помидор и др.); единичность обозначаемой словом (словосочетанием) реалии при отсутствии других лингвистических оснований не является диагностическим признаком онима и не может служить основанием для употребления прописной графемы, равно как и принадлежность языковой единицы к какому-л. множеству необязательно влечет за собой понижение буквенного регистра (Нечаева, 2017, с. 149-151).

Необходимо также иметь в виду, что в области правописания ономастической (в широком смысле) лексики особую значимость имеет связь правописных решений с внеязыковой реальностью. Это может быть обусловлено меняющимся с течением времени общественным осознанием многих понятий (социальных, религиозных, политических и др.), а также появлением новых реалий и соответствующих им номинаций. Орфографическая норма в этой области нередко индивидуальна и зависит от традиции; при этом в правилах правописания невозможно охватить регламентацией все конкретные случаи. Кроме того, критерии орфографических установлений в данной области не всегда эксплицированы. Как говорил академик Я. К. Грот, «за правилами все-таки еще многое останется рбшать такту и здравому смыслу» (Грот, 1876, с. 359). Это усиливает роль аспектного орфографического словаря. 
Задача такого словаря - на конкретном лексическом материале дать ответ на вопрос, вынесенный в его заглавие: «прописная или строчная?». Данная орфографическая антиномия и единство основной лексикографической задачи предопределяют особенности макро- и микроструктуры словаря.

Источники возможных затруднений в употреблении прописной vs. строчной графемы составляют две группы случаев: первые связаны в основном с семантикой словарных единиц, вторые - с их структурой.

3.1. По семант и ке подлежащие лексикографическому описанию единицы составляют две большие группы: это а) моносемантические единицы и б) полисемантические (в том числе омонимические). В отношении последних очевидно, что многозначность предполагает необходимость смысловой дифференциации понятий при графическом их обозначении на письме. Примеры:

Группа A $\rightarrow \mathrm{a}$ (с изменением значения происходит замена прописной на строчную):

Будда 'имя основателя буддизма' - будда 'тот, кто достиг духовного просветления';

Ахилл 'мифологический персонаж' - ахилл разг. 'ахиллово сухожилие';

Жучка 'кличка собаки' - жучка 'о любой дворовой собаке';

Аляска 'полуостров' - аляска 'куртка';

Олимп 'гора в Греции; в мифологии - местопребывание богов-олимпийцев' - олимп перен. 'избранный круг, верхушка общества';

Тмутаракань 'древний причерноморский город' - тмутаракань и тьмутаракань 'отдаленная глухая провинция';

Калашников 'фамилия конструктора стрелкового оружия' - калашников разг. 'автоматическое стрелковое оружие, автомат';

Вавилонское столпотворение 'библейский сюжет' - вавилонское столпотворение 'о суматохе, беспорядке'.

Группа $\mathrm{a} \rightarrow \mathrm{A}$ (с изменением значения происходит замена строчной на прописную): запад 'сторона света' - Запад 'страны Западной Европы и Северной Америки'; орел 'птица' - Орел 'название города';

возрождение 'восстановление' - Возрождение 'эпоха культурного расцвета в Западной Европе в 14-16 вв.';

белая 'прилагательное женского рода' - Белая 'название реки';

лев 'животное' - Лев 'о человеке, родившемся под зодиакальным созвездием Льва'.

Группа A $\rightarrow \mathrm{A}$ (изменение значения не влечет за собой изменение буквенного регистра): Аполлон 'мифологический персонаж' - Аполлон 'о красивом мужчине, юноше';

Обломов 'персонаж одноименного романа И. А. Гончарова' - Обломов 'русский тип бездеятельного человека';

Ромео 'персонаж трагедии Шекспира' - Ромео 'влюбленный юноша';

Волга 'река' - «Волга» 'автомобиль'

и др.

Члены последней группы и подобные им могут быть охарактеризованы как переходные случаи, когда слово по своему статусу является не вполне онимом и не вполне апеллятивом. Обычно при этом говорят о неполном переходе собственных в нарицательные, условном употреблении тех или иных наименований, неокончательной утрате связи с носителем имени и т.п. 
В группе моносемантических лексических единиц не каждая из них подлежит словарному описанию. Поскольку аспектный орфографический словарь с вопросительной формулой в заглавии является, по сути, словарем орфографических трудностей, в нем не обязательно должны быть представлены члены тех тематических групп, ономастический статус которых безусловен и правописание не представляет затруднений: это общеизвестные антропонимы, простые (однословные) общеизвестные топонимы и др. Напротив, с максимально возможной полнотой должны быть описаны неоднословные моносемантические единицы и слова, представляющие ту или иную орфографическую проблему, например, имеющие в своем составе служебные элементы.

Среди моносемантических единиц выделяется категория слов, которые, несмотря на единство семантики, могут, как и полисемантические, иметь две противопоставленных орфограммы. У таких единиц неоднозначность отображения на письме связана с употреблением их в различных дискурсах. Примеры:

Президент 'глава государства' - в текстах официальных документов: Президент Российской Федерации, Президент Франиузской республики, Управление делами Президента РФ; президент - в иных контекстах: выборы президента, президент Билл Клинтон, встреча двух президентов, рейтинг президента;

Папа Римский 'глава католической церкви' - при официальном титуловании: Папа

Римский Франциск совершил таинство крещения в Сикстинской капелле Апостольского двориа; папа римский - в неофициальных контекстах: резиденция папы римского, выборы папы римского, папа римский Иоанн Павел II;

ваше (его, ее) величество - в нейтральных текстах; Ваще (Его, Ее) Величество - при официальном титуловании монарха

и др.

Существуют и более сложные случаи, когда семантические и дискурсивные различия оказывают одновременное влияние на орфографию слова, и это показывается в словаре. В этой связи нельзя не привести следующий пример:

1. бог, -а, мн. -и, -ов, напр.: бог Аполлон, боги Олимпа, Марс - бог войны, артиллерия бог войны (перен.)

2. Бог, -а (в христианстве и других монотеистических религиях: единое верховное существо), напр.: верить в Бога, молиться Богу

3. бог, -а (в ряде выражений преимущ. междометного и оченочного характера; употр. вне прямой связи с религией), напр.: ей-богу, бог ты мой, бог его знает, бог знает что (выражение возмущения), дай бог (высокая оценка чего-н.), не дай бог, помилуй бог (выражение несогласия или удивления), не бог весть, не бог знает что, не слава богу (неблагополучно), ради бога (пожалуйста, очень прошу), убей (меня) бог, как бог на душу положит, давай бог ноги; вот вам бог, а вот порог; иди ты к богу (в рай); ни богу свечка, ни черту кочерга (Лопатин, Нечаева, Чельцова, 2009, с. 79-80).

Не обойдем вниманием и еще одну категорию слов, представляющих тривиальную орфографическую трудность в отношении обозначения начальной гра- 
фемы: это производные от собственных имен. Несмотря на наличие довольно четких правил ${ }^{2}$, действует психолингвистический фактор графической аналогии у однокоренных слов. Это в основном относительные (чаще всего - оттопонимические) прилагательные, но также и существительные типа пугачевщзина; последние не следует путать со словами Псковщзиа, Смоленщина и т.п., которые сами являются собственными именами.

3.2. По структуре словарные единицы подразделяются на однословные и неоднословные. В отношении неоднословных возможны два варианта орфографирования: с прописной пишется а) только первое слово номинации (плюс входящие в нее онимы) или б) все составляющие данное наименование слова. По общему правилу в большинстве такого рода номинаций по русской письменной традиции повышенным буквенным регистром отмечается только первое слово; однако это не касается личных составных имен, географических, астрономических и административных названий (за исключением родовых понятий, пишущихся со строчной графемы) и названий некоторых организаций мирового значения (например, Организация Объединенных Наций). Приведем примеры различных номинаций, сгруппированных по тематическому принципу:

- антропонимы: Генрих Наваррский, Симеон Столпник, Феофан Затворник, Ричард Львиное Сердие, Лу Синь, Ким Чен Ир, Венера Каллипига, Джон Ячменное Зерно, Синяя Борода;

- топонимы и административные названия: Большая Курильская гряда, Великий Устюг, Новый Орлеан, Южное Пассатное течение, Северный Донеи, Нагорный Карабах, мыс Доброй Надежды, Соединенное Королевство Великобритании и Северной Ирландии, Большой Каменный мост, Выборгская сторона, Лебяжья канавка, Покровские Воротаз ;

- астронимы и космонимы: Млечный Путь, Большая Медведиц, Полярная звезда, Большая туманность Ориона, созвездие Южный Крест;

- хрононимы: Новое время, Петровская эпоха, Раннее Возрождение, Пятая республика;

- названия исторических событий: Великая франиузская револющия, Столетняя война, Бородинское сражение, Крымская конферениия, Брестский мир, Парижская коммуна, Великие географические открытия, Варфоломеевская ночь;

- названия различных предприятий, учреждений, организаций: Международньй валютный бонд, Российская торгово-промышленная палата, Российский гуманитарныцй научный фонд, Российское информаиионное агентство «Новости», Институт Франици, Медииинский колледж РАМН, Первая (1-я)

\footnotetext{
2 По правилу, существительные и относительные прилагательные, образованные от собственных имен, пишутся со строчной буквы, а притяжательные прилагательные - с прописной.

3 По правилу, нарицательные существительные в составе географических и административных названий пишутся с прописной буквы, если они употреблены не в своем собственном значении, ср. Сивцев Вражек (переулок), Покровские Ворота (площадь), Зацепский Вал (улица), а также Золотой Рог (бухта), Кузнецкий Мост (улица), Марьина Рощз (район) и т.п.
} 
градская больнии, Международная федерация гимнастики, Большой драматический театр, Малый зал Московской консерватории, театр Ла Фениче, Государственная Третьяковская галерея;

- названия дворцов, замков, храмов, монастырей, заповедников: Зимний двореи, Большой Кремлевский двореи, Фонтанный дом, вилла Боргезе, Инженерный (Михайловский) замок, замок Иф, Исаакиевский собор, собор Парижской Богоматери, храм Всех Святых, иерковь Покрова на Нерли, Голубая мечеть, Соловецкий монастььр, Оптина пустьнь, Байкальский заповедник, Беловежская Пуша;

- названия религиозных и культурных артефактов: Ветхий Завет, Младшая Эдда, Лунная соната, Медный всадник, Ростральные колонны, Пергамский алтарь, Сикстинская Мадонна, Янтарная комната, Розетский камень;

- названия наград, премий, призов, знаков отличия: Государственная премия, Нобелевская премия, орден Красной Звездь, орден Почетного легиона, Георгиевский крест, медаль «Ветеран труда», Золотая пальмовая ветвь, приз «Золотая маска»;

- названия праздников, календарных периодов, памятных дат: Новый год, Международньй женский день, Всемирньй день защиты детей, Татьянин день, День независимости, День города, День благодарения, День взятия Бастилии, Год ребенка, Пушкинский год, год Ломади (по восточному календарю) и мн. др.

Орфографическая проблема употребления прописной графемы у однословных словарных единиц касается прежде всего композитов, пишущихся через дефис. Подобные единицы на письме могут иметь одну прописную в начале слова или две прописных - в начале каждой из частей, разделенных дефисом. Иногда такие слова входят в состав неоднословных номинаций. Поэтому слова с дефисом обязательно должны включаться в словарь.

В орфографических правилах, которые простроены по принципу регламентации различных семантических разрядов лексики (географические названия, астрономические названия, названия исторических эпох, названия, связанные с религией и др.), не разъясняется логика нормообразования в данной области, однако словарный материал позволяет заметить наличие определенной системы. Правописание зависит от характера и происхождения номинации. Примеры:

Абу-Даби, Ай-Петри, Ла-Мани, Сьерра-Невада; Книппер-Чехова, Салтыков-Щедрин и т.п. (номинации являются либо антропонимами, либо топонимами и аналогичны тем неоднословным наименованиям, в которых все слова пишутся с прописной);

Гайд-парк, «Геликон-опера», Горбачев-фонд, Царь-колокол и т.п. (номинации аналогичны тем неоднословным наименованиям, в которых только первое слово пишется с прописной);

Южно-Американская платформа $\leftarrow$ Юная Америка, Северо-Атлантическое течение $\leftarrow$ Северная Атлантика (номинации образованы от неоднословных собственных наименований, в которых все слова пишутся с прописной);

Горно-металлургическая компания $\leftarrow$ горная металлургия, Военно-исторический архив военная история (номинации образованы от нарицательных словосочетаний). 
Другая проблемная группа структурно сложных единиц (однословных и неоднословных) - онимы, имеющие в своем составе служебные элементы (русские и иноязычные). Существует правило, по которому такие элементы (артикли, предлоги и другие служебные слова) должны писаться со строчной графемы; однако, поскольку написание подобных имен в максимальной степени подчиняется традиции, а у иноязычных единиц может также зависеть от орфографии языка-источника, встречаются различные случаи (иногда обнаруживающие традиционную непоследовательность). Примеры:

Франкфурт-на-Майне, Рио-де-Жанейро, Шарм-эль-Шейх, Па-де-Кале, Ла-Манш, Ла Скала, Васко да Гама, Ди Каприо, Кер-огльь, аль-Капоне, Абу Али ибн Сина, Турсун-заде, д’Артаньян, Д’Аламбер, Ван Гог и др.

Многообразие лексического материала и его особый характер обусловливают необходимость поиска оптимальных форм словарного описания, главная цель которого - полнота и информативность представления материала во всей его специфике. С этим связаны, помимо макроструктурных, и микроструктурные особенности аспектного орфографического словаря. Постатейное алфавитное расположение всех проблемных слов и словосочетаний возможно, и оно имеет свои достоинства. Но наиболее информативным представляется совместное описание орфографических коррелятов в виде особого словарного комплекса, включающего все пограничные случаи. Поэтому словарная единица и словарная статья в словаре данного типа - это не одно и то же. Примеры словарных комплексов:

1. академия, -и (не в начале названий учреждений), напр.: Российская академия наук, Московская сельскохозяйственная академия им. К.А. Тимирязева, Военная академия им. М.В. Фрунзе, Дипломатическая академия МИД, Финансовая академия при Правительстве РФ

2. Академия, -и (философская школа Платона в Афинах)

3. Академия, -и (как первое слово в названиях учреждений), напр.: Академия Российская $($ ucm.), Академия наук СССР, Академия военных наук, Академия народного хозяйства при Правительстве РФ, Академия гражданской авиации, Академия славянской культуры, Академия русского балета им. А.Я. Вагановой (...)

4. Академия, -и (в геогр. названия $x$ - в знач. «имени»): хребет Академии Наук (на Памире), залив Академии (в Охотском море) (Лопатин, Нечаева, Чельцова, 2009, с. 48).

1. земля, -и (суша; почва; территория как объект владения и использования)

2. Земля, -и (название планеты, астр.)

3. Земля, -и (наземный центр руководства полетами)

4. земля, -и (в ист. названиях областей, территорий), напр.: Новгородская земля,

Галицко-Волынская земля, Вятская земля (...); также: Святая земля (Палестина)

5. земля, -и (в неофии. названиях стран, областей), напр.: Русская земля (Россия, Русь), Смоленская земля (Смоленщина), Рязанская земля (Рязанщина), Донская земля

6. земля, -и (в названиях федеративных единии в Австрии и Германии), напр.: земля Верхняя Австрия, земля Баден-Вюртемберг, земля Гессен

7. Земля, -и (в названиях островов, архипелагов, полуостровов, нек-рых территорий в Антарктиде, Гренландии, Австралии), напр.: Баффинова Земля (остров), Земля Георга (остров), Новая Земля, Белая Земля, Огненная Земля, Земля Франца-Иосифа (архипела- 
ги), Гусиная Земля (полуостров), Земля Виктории, Земля Королевы Мод, Земля Принцессы Елизаветы (в Антарктиде) (...)

8. земля, -и (материк): Большая земля (Лопатин, Нечаева, Чельцова, 2009, с. 185-186)

1. Палех, -а (поселок)

2. палех, -а (изделие народного промысла; также собир.) (Лопатин, Нечаева, Чельцова, 2009, c. 328)

1. Пальмира, -ы (древний город)

2. пальмира, -ы (веерная пальма; гарнитура шрифта)

3. Пальмира, -ы: Северная Пальмира (о Петербурге) (Лопатин, Нечаева, Чельцова, 2009 , c. 328)

1. форум, -а (главная площзадь в городах Древнего Рима), напр.: форум Августа, форум Траяна (в Риме)

2. форум, -а (перен.: представительное собрание), напр.: Всемирный экономический форум (Давосский форум), Всероссийский промышленно-экономический форум, Всемирный молодежный музыкальный форум (Лопатин, Нечаева, Чельцова, 2009, с. 463).

Представляется, что объединение членов полисемии в едином комплексе полезно, даже если по лингвистическим основаниям они не различаются написанием (как в случае со словом форум). Таким образом, словарь содержит как языковую, орфографическую, так и экстралингвистическую информацию одновременно. Совмещение лингвистического и энциклопедического аспектов словарного описания - органичное свойство словарей подобной направленности, что вполне соответствует тенденциям современной лексикографии.

\section{Библиография}

Букчина, Б. З., Калакуцкая, Л. П. (1987). Слитно или раздельно? Опыт словаря-справочника. 3-е изд., испр. и доп. Москва: Русский язык.

Грот Я. К. (1876). Спорные вопросы русского правописания от Петра Великого доныне. СанктПетербург: Типография Императорской Академии Наук.

Грот, Я. К. (1888). Русское правописание. 7-е изд. Санкт-Петербург: Типография Императорской Академии Наук.

Зализняк, А. А. (1979). О понятии графемы. Balcanica. Лингвистические исследования. Москва: Наука, с. 134-152.

Крысин, Л. П. (2013). Словари современного русского языка. Типы словарей. Славянская лексикография. Москва: «Языки славянской культуры», с. 542-563.

Лопатин, В. В. (2001). Прописная буква в орфографическом словаре общего типа. В: Словарь и культура русской речи. К 100-летию со дня рождения С. И. Ожегова. Москва: Индрик, c. 251-258.

Лопатин, В. В., Нечаева, И. В., Чельцова, Л. К. (2007/2009/2011). Прописная или строчная? Орфографический словарь. Москва: ЭКСМО.

Нечаева, И. В. (2017). Прописная графема и ее функции в современном письме. Русский язык в научном освещении, № 33, с. 143-161.

Розенталь, Д. Э. (1984). Прописная или строчная? Опыт словаря-справочника. Москва Русский язык.

Русский орфографический словарь (1999). Под ред. В. В. Лопатина. Москва: Русский язык. 
Сазонова, И. К. (1999). Орфограбический словарь русского языка: Одно или два н? 2-е изд. Москва: АСТ-ПРЕСС.

Суперанская, А. В. (1973). Общая теория имени собственного. Москва: Наука.

Чельцова, Л. К. (2009). О правилах употребления прописной буквы. В: Лингвистические основы кодификации русской орфографии. Москва: Азбуковник, с. 247-271. 